\title{
Dictynna
}

Dictynna

Revue de poétique latine

$3 \mid 2006$

Varia

\section{Playing at Lyric's Boundaries: Dreaming Forward in Book Two of Horace's Sermones}

\section{Kirk Freudenburg}

\section{Q OpenEdition \\ 1 Journals}

\section{Electronic version}

URL: http://journals.openedition.org/dictynna/228

DOI: $10.4000 /$ dictynna.228

ISSN: 1765-3142

\section{Electronic reference}

Kirk Freudenburg, «Playing at Lyric's Boundaries: Dreaming Forward in Book Two of Horace's Sermones », Dictynna [Online], 3| 2006, Online since 18 October 2010, connection on 10 September 2020. URL : http://journals.openedition.org/dictynna/228 ; DOI : https://doi.org/10.4000/dictynna.228

This text was automatically generated on 10 September 2020 .

\section{(c) (i) (9)}

Les contenus des la revue Dictynna sont mis à disposition selon les termes de la Licence Creative Commons Attribution - Pas d'Utilisation Commerciale - Pas de Modification 4.0 International. 


\title{
Playing at Lyric's Boundaries: Dreaming Forward in Book Two of Horace's Sermones
}

\author{
Kirk Freudenburg
}

Hoc erat in votis: modus agri non ita magnus, hortus ubi et tecto vicinus iugis aquae fons et paulum silvae super his foret. auctius atque

di melius fecere. bene est. nil amplius oro, Maia nate, nisi ut propria haec mihi munera faxis. 'This was in my prayers: a measure of field not so big, where I might have a garden, and right next to the house a spring that always flows. Up above a small stand of trees. The gods have provided more amply and even better. It's fine, and I won't ask for anything more, Son of Maia, except that you might make these gifts really mine.'

1 Pointing forward to a small but lovely picture of the poet's new farm, the opening words of Sermones 2.6, hoc erat in votis, put us in mind of a votive tablet, with the gift granted by the god duly pictured within a small, three-line frame. ${ }^{1}$ Because the brushstrokes are broad, the picture tells us little about the farm itself other than that it had what all decent farms should have: fields, house, water, trees. The poet asked for just "this" (hoc), the basics, but he was given a great deal more. The details of what he received, and exactly how his farm was better and more ample (auctius atque...melius) than what he prayed for, he does not say. For what the poet leaves us to ponder is no full-scale inventory of his new holdings, but a humble votive sketch, lean in detail, but rich with heartfelt gratitude. A very pretty picture.

2 The poet's gesture of thanks tells of favors divinely granted and personal happiness achieved. For this small moment at least, the speaker seems to have "arrived" and to have nothing much to complain about. And that makes him immediately problematic 
as a satirist. One may recall, for example, how a shivering Hipponax once prayed to Hermes asking not for a dollop of honey to sweeten his cake, but for a cloak and a pair of sandals to keep his "chillblains" from bursting. ${ }^{2}$ And that ruse of the complainer's dire social abjection became one of the more predictable features of the satirist's selfpresentation in the larger iambographic tradition to which both Hipponax and Horace belong. In being so beautifully favored by the gods, actually receiving even more than he asked for, there is no one quite like the well-kept poet of Sermones 2.6 in Lucilius or in Sermones book one. There satire's speakers are overwhelmingly unhappy with the political and social worlds that surround them, and they have much to complain about in their personal lives as well. Still, there are exceptions to the rule of the satirists" discontent. And there are several features of this rare, and apparently "happy," scene that are in keeping with a set of new and softer rules of the genre that Horace sets out for our consideration in Sermones 2.1. In that programmatic first poem the poetinterlocutor reminded us that not only did Lucilus make direct personal attacks on prominent political figures of his day, he occasionally wrote satires in a completely different register that featured him in a relaxed, private mode, far from the public scene, sporting with his friends, Scipio and Laelius. Lucilius" third satire told us about the hazards and personal annoyances of a trip to Sicily - something Horace reminds us of in book one. One poem apparently found the poet chasing Scipio around the dining room, snapping at him with a twisted napkin. ${ }^{3}$ Other poems tell us about the poet's love life, the dinners he attended, his drinking habits, and so on. All of which Horace brings to mind in Sermones 2.1 when he says that the old man splashed his "entire life" across the pages of his satires like so many overdone details on a votive tablet (picta tabella). And it is in this alternate, "confessional" direction, already sampled in book one, that Horace steers his second book. Here the poet steps away from the public censorial role that he tried on for size in book one, only to find that Lucilius" shoes were laced too high for a man of his diminutive stature. And instead he treats us to snatches of his private life, his time spent among friends and his daily routines. To write this way is to perform in an alternate mode of Lucilian satire, that of his autobiographical poems, but the end result is anything but Lucilian. ${ }^{4}$ For Horace's scenes from life, unlike those remembered from Lucilius, are reticent and frustratingly under-detailed, much as the farm picture he leaves us to ponder in 2.6. And they add up differently, to suggest that this poet is not in fact his own man, and that he has no life at all. As always in the Sermones, in trying to live up to Lucilius, even in this softer, personal mode, the joke ends up being on the poet himself. Eavesdropping on his daily routines we see that the company he keeps is mostly not of his own choosing. His ranking with Octavian and Maecenas, again something he tells us frustratingly little about, has made him an object of public attention, much of it unwanted. Accordingly, much of the conversation he has us listen in on in this book is meaningless, one-sided, and/or extreme, the result of his being too frequently buttonholed and browbeaten, a second-tier celebrity with ties to the real thing. With his own life now squarely under satire's microscope, he has to take in book two what he dished out to others in book one, as he is subjected to the moral scrutiny of various "experts," many of whom sound curiously like himself. Throughout the book they insist that he take notice of them, hear them out, and (though they never say so) become their friend.

3 From this wide-angle view of the genre, the votive vignette that opens Sermones 2.6 has some claim to being unexceptional as "satire" in the Lucilian manner, and thus to both belonging to its book and neatly instancing its habits. But the pictures painted all 
around this one, the ones I have just alluded to, are chock-full of personal discontent, social commentary and comical fun, and that is key to their being taken for satire in the Lucilian manner. This scene, too, needs a bit of what they have to register as satire, and it in fact derives a good deal of self-critical potential from its being suggestively placed to underscore Horace's own social climbing and hypocrisy. ${ }^{5}$ Moreover, despite its happy coloring, it fails to tell a tale of bliss truly achieved by missing one key element: the poet himself. As he describes it, the villa he has been given, while lovely and inviting, is empty. The poet is nowhere in sight. Rather, he ponders his new farm wistfully from some distant, urban locale, wishing he could include himself in the scene he paints. But he cannot. Any respectable picture of true, god-given bliss should feature the owner tending his fields, plucking fruits, or drinking from his spring. But that is the stuff of lyric, not of satire, where the poet is generically bound to drag out his life in the big city, and where there can be no running off to rustic bliss. When Horace tries to do this in Sermones 2.3 he manages only to drag with him a very loud and ungainly chunk of the city, in the person of the street-preacher and reformed antiques enthusiast, Damasippus. This poem's opening lines contain the first mention of Horace's villa in his published works, describing it as a "sweet little farm" (villula) to mock Horace's precious, desiring mindset about it. As Damasippus lays into the poet for running off to the countryside he casts him in an as-yet unfamiliar light (Sermones 2.3.1-10):

'You write so sparingly that you call for the parchment hardly four times in an entire year, always unweaving all you've written, and you're mad at yourself because, too liberal with wine and sleep, you sing nothing worthy of talk. What's the point? But you've fled to this place, stone sober right at the time of the Saturnalia! O.k., so say something worthy of what you've promised. Go ahead! Nothing. Pointlessly you blame your writing instruments, and your innocent wall gets battered, born when gods and poets were in a bad mood. Yet yours was the face of one threatening many glorious things, if only your sweet little villa should catch you, freed of duties, under its warm cover.'

4 Except for the detail taunting the poet's sparing rate of production, the picture Damasippus paints is out of keeping with anything we know of the satirist from personal details encountered earlier in either book. Here, for the first time in the Sermones, we are presented with a moralist oddly disengaged from city life, running off to his farm to escape the noise and bother of Rome at the height of the Saturnalia, when all good satirists should be busily about their business in the city. ${ }^{6}$ As berated by Damasippus, Horace is listless and undirected, overfond of wine and sleep. In sum, no satirist at all. But he is not entirely unfamiliar to us. On the contrary, the set of traits picked out by Damasippus adds up to a version of Horace that we know quite well, that of the subumbral lounger, fond of rustic detachment, wine and sleep. It is a version of the poet altogether familiar from the Odes, but quite out of keeping with his selfrepresentation in the satires. His appearance here in Sermones 2.3 constitutes another first that will be reiterated in poems 6 and 7. At the end of Sermones 2.3 Damasippus complains about the poet's "latest poems" (poemata nunc 321) by suggesting that they are proof of his being over-inflated (cum magis atque / se magis inflaret, 318-19) and reaching too far. The poems are "inspired," in other words, and cast in a much loftier/ nobler register. None of which (not even the designation poemata) applies very well, if at all, to his satires, but all of which applies beautifully to his songs of love, or to certain of his Epodes that stray from their iambographic center towards Lyric expressions of love. In his parting shot against him, Damasippus complains that the poet is mad in his pursuit of lovers, raging after girls and boys by the thousands. It seems that, in reading 
Horace's latest (nunc poemata), Damasippus has noted even the poet's famous (Epicurean) penchant to stray abruptly from one love to the next. ${ }^{7}$ The charge that he suffers "a thousand mad passions for girls, and another thousand for boys" is a mad claim that adds to the sense of Damasippus" being himself unsettled by rage. But the claim, however outlandish it may be as a description of anyone's actual habits, is fully in keeping with the inflated claims made by mad lovers in song. As evidenced, for example, in the lyric poetry of Anacreon, where the singer repeatedly relishes in the twin "furies" (maniai) of inebriation and sexual desire (Anacreon PMG 9, 12, and 60). At Anacreontea 14 the poet sings of having countless lovers in every far corner of the world, including no less than "two thousand" lovers closer to home, in Lesbos, Ionia, Caria and Rhodes. The habits Damasippus berates, crazy as they seem, are all standard tools in the lyric lover's kit. And although they stand at odds with the habits described of the poet in all the poems that precede in the Sermones, they are all staples of the poet's Sabine existence in Odes Books 1-3. Oddly (or perhaps this is part of what is implied by Damasippus" rage) a narrow strain of the Greco-Roman critical tradition would end up berating Anacreon in precisely the same terms that Damasippus uses to denigrate Horace, as a drunkard, voluptuary and a skirt-chaser. And all the proof that Anacreon's critics needed to support their claims was his poetry. ${ }^{8}$ Morally loose habits clearly belong in satire, as they do in certain strains of lyric poetry. But they belong there differently, as Damasippus clearly shows in his "step aside and I'll show you how it's done" strain of satire (diatribe, exaggerating the habits of Sermones 1.1-1.3). They are there to be cartoonified and mocked by a satirist who is both cleanly separate from them and intent on their eradication.

5 The first-ever mention of Horace's villa thus brings with it a new perspective on the poet's self to suggest that there is a Jekyll-and-Hyde quality to the poet's existence that toggles on a city/country switch. The poet's shirking his duties as a satirist, and that newfound country home of his, somehow entail one another, functioning for Damasippus within a single conceptual matrix. In line 4 Damasippus berates the satirist with the curious charge nil dignum sermone canas "you are singing nothing worth talking about." Anyone who has read the Sermones through to this point knows that Horace is painstaking about his generic terminology. Sermo is Horace's preferred word for "satire," but nowhere else does he use the verb canere "sing" to refer his "talks/ conversations". ${ }^{9}$ But here, in another stunning "first," we are asked to imagine this poet singing his talks. Or perhaps not. ${ }^{10}$ The point may rather be that with the new villa have come new expectations and a new generic mode, that of lyric (Carmina "songs'). With the new generic mode have necessarily come new means of self-expression, and that leaves us, along with Damasippus (an inset reader/interpreter who, in some sense, speaks for Horace's reading public, or some narrow strain of it) to deal with an utterly new sense of the poet's self. The man who, on paper, used to seem so responsible and driven by moral purpose is now caught performing in the role of one of his genre's stock villains, i.e. the social climber and playboy. For Damasippus the problem is not that the playboy satirist is producing nothing at all, it is that he is singing "song" that is worthless as satire, because it is removed from urban life, pleasurable in tone, and morally adrift. In sum, it isn't decent satire because not only does it fail to measure up to Damasippus" narrow definition of sermo, but because it isn't satire at all. By leveling his complaint about "songs" overtaking satire and preventing the poet from finishing his book, Damasippus voices the concerns of an audience that has waited fully five years or more for the publication of a second book of satires. In that respect he stands- 
in for the readers of book one who expect him to deliver a completed second book, and who might well expect him to remain true to his old responsible self. But Damasippus is, even more pointedly and perfectly, the stand-in for Maecenas (Da-Ma-sip-pus), the man to whom the poet's "if only I had a villa" promise would have been made (if it ever was made), and who might well have been wondering (with us) when that book he "promised" (promissis) would finally see the light of day. We recall that in Epode 14, a clear match for Sermones 2.3 in its theme, figurative habits and time of composition, it is Maecenas who incessantly demands to know when the "promissed song" (promissum carmen), referring to the Epodes themselves, would be done. Once again in this poem the problem of the poet's failure to finish the book he started (inceptos iambos) is put in terms of his pursuit of reckless pleasures: he has fallen in love with Phryne, he says, a freedwoman who shares a famous prostitute's name, and she has lulled him into a state a state of pleasurable and unproductive somnomulence that keeps the iambic-writer from writing pissed off poems. ${ }^{11}$ Writers of iambs, such as Archilochus, were notoriously unlucky in love. Their failures and broken affairs were a ready source of rage driving them to complain and taunt.

But in this case the "lyric" dimensions of the poet's excusing himself as a playboy are even more pronounced than they are in Sermones 2.3. He cannot finish the book, the poet says, because a god (Love) prevents him (deus deus nam me vetat, 6). Watson points out that this is "the most obtrusive piece of Callimacheanism in Epode 14...that is to say, a god who, like Apollo in the Aetia preface or the recusatory prooemium to Vergil Eclogue 6, directs the poet away from one genre - in this case iambus - and towards another, which, unusually, is not here stated but only implied. ${ }^{12}$ The implied genre becomes immediately clear in the lines directly following, where the poet claims that he is deeply distracted by his love for Phryne, "just as they say Anacreon of Teos once burned for the Samian Bathyllos, and lamented that love obsessively in uncomplicated rhythms sung to the lyre." A number of scholars have maintained that what connects Horace to Anacreon here is not simply their shared passions for lovers who tend to sleep around, it is the lyre itself as a means of lamenting that love in song. ${ }^{13}$ Anacreon, one of the nine canonical poets of Greek lyric, is with Alcaeus and Theognis one of the main models for Horace's sympotic songs. He sang of being pleasurably tortured, and teased, and gratified by his many lovers and would-be lovers. Bathyllus (see Anacreontea 17, a poem that Horace would have regarded as authentic ${ }^{14}$ ) is only the most famous of these. ${ }^{15}$ In a number of poems Anacreon sang of growing old but refusing to grow up, despite being teased for the grey hairs on his head (Anacreon PMG 358, and Anacreontea 7, and 51). He sang of wine, of banquets, and song, and of the need to take a full measure of delight from these because life, like a bright red rose, fades quickly (Anacreontea 32 and 36). He tells of his incapacity for any higher, "nobler" brand of song that praises the achievements of famous men (Anacreontea 23). He represents a haughty girl as a skittish filly (PMG 417). He sings of tossing his shield aside (PMG $381(b)=85$ Gentili), and he even dreams of sprouting wings (PMG 378 and Anacreontea 30). Seen from this background, and with due consideration for what Horace will make of him in subsequent song, the reference to Anacreon in Epode 14 is not a casual gesture that loosely links one lover to another. Rather the gesture points to the poet's other life performed in an alternate generic mode, and to a specific set of self-expressions that will go with that alternate life, as a writer of Anacreontic songs. This poem is itself a way of sampling that alternate mode from within a suitably accusatory ('where's the damn book, Horace?!') iambic milieu. So heavily does it gravitate towards the themes 
and expressive habits of lyric love poetry that much scholarship on the poem has addressed itself to the question of whether it ought to be classified as iambic or lyric. ${ }^{16}$ Anacreon's remembered love for Bathyllus is neatly couched within a generically problematic poem to function as a generic sign representing the lyric play that keeps Horace from his assigned and half-done epodic work.

In Sermones 2.3 the genre markers are less obvious, but perfectly consistent with the idea that other types of poetry are being looked to and distracting the poet from completing his book. Here again, genres are marked by exemplary names. At lines 11-12 Damasippus says:

Quorsum pertinuit stipare Platona Menandro?

Eupolin Archilocho, comites educere tantos?

"What was the point of packing Plato in with Menander, and Eupolis with Archilochus, bringing travel-companions with you as great as these?"

Scholars have long puzzled over the exact generic implications of this list of names. And elsewhere I have done my part to add to the confusion by insisting that Damasippus is here talking only about the satires, perhaps rigging his list to include models he thinks worth emulating in satire (thus providing a personally focalized list, expressive of his values). But a far better solution comes to hand when one simply considers what works Horace was actually on the verge of completing in the late 30's B.C. and that a bookbag filled with these particular writers would help him complete. If we take the reference to Archilochus in its most obvious sense, as a cross-generic nod towards the Epodes, where Archilochus is the work's principal model, things add up very nicely. ${ }^{17}$ Plato and Menander refer us to Sermones book 2, while Eupolis and Archilochus put us in mind of the poet's iambic performance in the Epodes. One would be hard pressed to find two more perfect model-pairs for either work. The fact that the projects that these names best fit were as yet unfinished in the late 30's, and that Damasippus" complaint specifically treats the poet's failure to finish, should help us nail down the substance of Damasippus" complaint in terms that make sense not only as literary fantasy, but that actually bear upon the known facts of the poet's professional life. In the immediate aftermath of Actium, Horace has two unfinished books on his desk, Sermones book 2 and the Epodes. But Damasippus complains that some third distraction has gotten in his way. From within the hard-hitting, cynical, and urban worlds of the Sermones and Epodes this distraction is troped as pleasurable and meaningless, and it seems to have something to do with the poet's new villa and the life that he enjoys there, as if the new place and the new life are somehow two sides of the same coin. That is the basic critique we have before us just ten lines from the beginning of Damasippus" tirade. As a description of the satirist we (think we) have come to know, Damasippus" words are baffling, and they leave us to wonder: does this villa have some new poetic agenda attached to it? Damasippus" peculiar troping of that terrain as a sweet retreat of wine, women, and especially "song" leaves little doubt as to what that distracting" project might be. ${ }^{18}$

In Sermones 2.6 Horace treats us to a different perspective of his new villa, figuring it as a welcome retreat from his harried existence in the city. Through his own eyes the view is attractive rather than unseemly, but when he dreams of going to his villa in lines 60-63 we cannot help but notice that the activities he describes himself engaging in are precisely the same activities that Damasippus chides him for at the beginning of Sermones 2.3. He will bring along a stack of classic books of old writers (veterum libris), he says, but he will sleep away his time and get nothing done (somno et inertibus horis 
ducere sollicitae iucunda oblivia vitae). This peculiar nexus of ideas has a clear counterpart (probably remembered, but perhaps anticipated) in the opening lines of Epode 14:

Mollis inertia cur tantam diffuderit imis oblivionem sensibus,

pocula Lethaeos ut si ducentia somnos arente fauce traxerim.

10 In both poems Horace figures "oblivion" as something he drinks in. Whereas in the Epodes the reference to the river Lethe is explicit, in 2.6 it hides in the idea that the poet's former life (sollicitae vitae) can be utterly forgotten by drinking in the pleasures of the farm. It is as if the river Lethe (= Latin Oblivium) flows through his country dreamscape, the waters from which the souls of the dead must drink upon being reborn..$^{19}$ Country draughts, he suggests, restore the soul. So, too, the food that he dreams of eating at his farm, especially "the bean, Pythagoras" kinswoman" (faba Pythagorae cognata, 63). That sounds a second reincarnational note by reminding us of Pythagoras and his odd transmigrational beliefs regarding beans..$^{20}$ The Platonic/ Pythagorean coloring of life on the farm will continue right through to the philosopher's symposium that ends the poem.

11 Besides feasting on simple greens, the poet admits that there will be drinking at the farm (just as Damasippus said there would be), some of it heavy, some of it light. Each guest, the poet says, will drink just what he wants, and no one will force him to drink any more. And that is very unlike the way drinking parties are conducted in the city, where some guests are required to drink more or stronger wine, and others less or weaker wine, or nothing at all. It all depends on who you are and why you were invited (if you were invited) in the first place. Horace can dream of escaping all of this nonsense because at his farm he is the boss, a point he emphasizes from the very start of the poem by calling himself the villa's exalted dominus (line 14). This is his house (larem proprium, 66), he makes clear, so the dinners and the drinking will be as he dictates. Here at his farm he is not a mere guest (conviva) but a host, and that makes for another stunning first in the world of Horatian Sermo. Nowhere else in either book of the Sermones do we find Horace in the role of host. But the activity of hosting is a ubiquitous concern in these poems, a habit deeply scrutinized by the poet as an index of the host's moral self. The eye-view of the satirist is routinely that of the put-upon guest who sits in an inconspicuous low seat. From there he sees it all, and he has much to say about the behavior he observes. In the key programmatic terms of Sermones 1.1 he is the conviva satur, the sated and tipsy dinner-guest who has a good time, speaks his mind, but has reserved just enough of his wherewithal and good sense to refrain from speaking abusively, and to know when it is time to get up and leave. ${ }^{21}$ Horace frequently plays this abused and/or over-indulging guest in his Sermones, but he is never the host. That is, not until he goes off to his country dreamscape in Sermones 2.6, where for the first and only time in his food- and drink-intensive satires, he actually hosts a gathering of friends (thus allowing himself to be indexed and deeply scrutinized by us, with the help of the fable-teller, Cervius). Elsewhere in these poems when the poet dines at home he does so in the exalted company of his earthenware cups and his oil jug. ${ }^{22}$ The food that he serves when keeping to himself is always, as here, simple and healthy, and thus radically unlike what he eats when tagging-along with Maecenas. But it is not shared with others. Ever. Somehow the farm allows him to break, or at least to dream of breaking, what is otherwise a basic generic ruse/rule. Thus, once again, running off to the country finds the poet altering certain of his well-worn habits, but in 
ways that are actually familiar to us from our subsequent reading of "him" in the Odes. There we remember that the poet's standard role is the complete opposite of his standard sympotic role in the Sermones: he is the host who issues invitations rather than chases after them. At his lyric table, he welcomes friends, toasts their health, and dictates the rules of the feast. In the world of the Odes it is they who have to behave themselves and know when it is time to go.

Both Sermones 2.3 and 2.6 make clear that Horace is a different man on his farm. They are consistent about this. But whereas the former poem chides him as a wastrel, the latter figures him as transfigured and reborn, not wasting away in love, but discussing the highest matters of man's moral existence over a few drinks with friends. Oddly the two representations, one hostile the other friendly, draw on precisely the same set of habits to reach their opposite conclusions. But among the nasty habits he is chided for in 2.3 is his "singing" some manner of song that Damasippus regards as (lit.) "not worthy of sermo." And again in 2.6 the poet indicates that the farm is a place where he can indulge himself in song. At lines 16-17 he wonders aloud:

'Therefore, when I've moved myself out of the city up to the mountains and to my citadel, what am I to lend lustre to first with satires and a muse that walks?'

Directly on the heels of his prayer to Mercury in lines 1-15, the poet plays up his special Mercurial powers by moving swiftly from low city-level to mountain peak in the space of one hexameter line. And as in 2.3 , the poet's removal to the country has a decided effect upon his poetry. Transported to his high, mountain perch, the poet awaits inspiration from a prosaic, ground-level muse, famously incapable of song, and he immediately launches into a hymn of praise modeled after Pindar's second Olympian Ode. ${ }^{23}$ It is an odd, oxymoronic moment that produces a strong sense of generic displacement as the satirist, stuck in the city but dreaming of the country, tries his hand at mountain-top, muse-inspired song. The tense coupling of illustrem satiris in line 17 underscores the oddity: illustrem has strong associations with epinician praise, and satiris equally strong (and exclusive) associations with invective. ${ }^{24}$ The terms naturally repel one another: how can this poet imagine himself "shedding lustre" through satire's notorious abuse? ${ }^{25}$ The song that follows is equally disorienting, a perfect blend of praise that blames. Here we have a hymn to a god, Matutinus, god of the rat-race, "praised" as the chirpy, rise-and-shine bastard that gets Horace out of bed every morning before sunrise. The hymn comes complete with the standard quid prius priamel and "how do I name thee" topoi of its several "straight" counterparts in the Odes. ${ }^{26}$ It lists the dangers, drudgeries, and petty snipings, all details of the singer's daily routine, that are this god's precious gifts. All quite funny, but hardly a "real" hymn.

But that, I think, is the point. This is not just what a hymn happens to look like in satire, it is what a hymn hasto look like in satire: scoffing, cynical, and parodic. This muse can drink (Lord, how she can drink!), but she cannot fly. Stuck in Rome, stuck in satire, Horace can only dream of his citadel, and of the higher kind of inspiration it will bring. Still, in dreaming, he has the urge to sing: tu carminis esto / principium (22-3). But his muse drags him down. For in trying to sing that hymn here, in satire, and having it sound the way it sounds, Horace shows us the upper limits of the genre in which he is currently enmired. The resulting "hymn" is parodic and laden with complaint, and that is satire's way of speaking, i.e. not where it fails, but where it succeeds. But the hymn's humor is tinged here with an edge of regret that tells of satire's never being able to rise above the scoffing, parodic mode, to the higher kind of "song" that post-Actian 
pressures now demand. So in asking "whom do I praise first," the poet sets us up for another fall: we expect Mae-ce-nas but get Matu-ti-ne instead. The chosen designation plays upon the very expectation it dodges, for we know that Maecenas really is the one getting the poet out of bed (he says so just a few lines later). It is his salutatio that has to be raced to first thing, and his duties that the poet is always about. So in praising Father Daybreak, Horace praises Maecenas in a weird, ribbing way that is satire's only laudatory mode. For the real thing the citadel has to be scaled, and its high inspiration imbibed, not just dreamed of. There, in "song" (carmen), Maecenas can claim pride of place as the true principium "start" from which all else follows (Carmina 1.1):Maecenas atavis....

That is one admittedly neat and "helpful" way to read the poet's comical foray into hymnody in Sermones 2.6. That is, by means of such a reading I have helped (my) Horace organize his life into a fixed set of discrete generic modes, thus rendering "him" organized, fully respectful of generic boundaries and sensible. Just as I need him to be. Another way to read the hymn would be to let it express something about how things will happen in his Odes, with mockery signaling not satire's limits but the problems that we are bound to face in dealing with a singer who is hard-to-label and prone to generically mixing his songs. Looking ahead to what follows in his career we might ask, can this poet ever, will he ever, sing a "straight" hymn of praise? Will he ever play up the achievements of Octavian, soon to become Augustus, in song, in ways that the princeps himself would encourage or credit as the real thing? Or is he not always caught in the act of dodging, recusing himself, and managing to keep one foot squarely in satire's low, jestive plains by straying uncontrollably towards ironic ribbing and talk of personal pleasures even when he sings of heroes and wars and the greatness of Rome (nunc est bibendum...)? These are questions that do not simply disappear with the publication of Odes books 1-3. Rather, they are intensified by that performance, and actively dwelt upon from the start of Odes 1.1, where the poet tells us that this will be a creative mix of tunes taking us back not to one, but to several, if not to all the great canonical singers who hit it big on the Alexandrian charts. Those who like their singers to stay true to their tune, and to sleep only with the muse that they brought to the dance, won't like these songs. They are prone to straying off in multiple generic directions, in multiple styles and to not stating the obvious.

The failure to name, and suitably thank, Maecenas for his new villa is one of the more telling (and ode-like) oddities of Sermones 2.6, which raises as a central topic (lines 40-58) the problem of what the poet can and cannot say as a friend of the great. All of which relates to the problem of writing satire after Actium (see below). In line 5 the poet suggests that Mercury, Maia nate "the son of Maia," gets chief credit for his success, and that is another curious instance of the poet's mouthing the obvious while appearing to name someone else. We know full well whom the poet should be thanking for his farm, and the name in question does start with the letter M. Commentators on the passage normally explain that Mercury is the god of gain and of unexpected windfall, and that works well enough as loose-fitting solution. But I am not the first to notice that the designation "son of Maia" Maia nate, is the perfect rhythmic and sonic replacement for the one we really expect him to thank, Maecenas. ${ }^{27}$ And so, just as with Matutine a few lines later, the designationcan be heard to both acknowledge and dodge the real source of the poet's magnificent success. The clever circumlocution may thus be heard as a genre-bound gesture of thanks that plays at the boundaries of what satire can say, hinting at saying "thank-you Maecenas, you are an amazing and generous 
friend" without actually saying it. And by playing at the boundaries in this way, the punning gesture of thanks puts us in mind of one of the genre's crueler oddities: satire purports to speak freely, whatever the poet wants to say, and it can sometimes come close to giving a dear friend his sincere and un-ironical due, but it can never say anything as simple and heartfelt as that.

But there may be yet other non-assonantal aspects of the god Mercury that privilege his being named above all others at the beginning of Sermones 2.6. Elsewhere in his works Horace is explicit about his having a special connection to the god, as at Odes 2.17.29, where he numbers himself among the Mercurialium virorum, that is, men born under Mercury's sign and thus especially favored by him and endowed with his special gifts. ${ }^{28}$ Foremost among the god's gifts to the poet, as he reminds us many times, is the lyre. This is the special gift that Horace attends to in C. 1.10, the first formal hymn of the Odes, where the god is praised for crafting the instrument and giving it to mankind as his special, enculturing invention. And it is primarily this aspect of the god's power that Horace dwells on elsewhere in his works. ${ }^{29}$ It is in that special and deeply personal sense that Horace is a vir Mercurialis in his Odes. And perhaps already here in Sermones 2.6, for there is an obvious poetic coloration to the god's powers as they are detailed in the elaborate "if...then" prayer of lines 6-15. What commentators have failed to note about the prayer's drawn-out protasis is that it addresses Mercury in not one, but two key aspects of his power. Lines 10-12 pray to him as a god of financial windfall (thesauro invento) and of buying and selling (mercennarius...mercatus). That is obvious enough. But lines 6-9 address him in a different way, as a keeper of boundaries; namely, as the god whose powers mark off what is "one's own" (propria) from what belongs to others. It is in reference to that specific power of the god that the poet promises that he will not reduce the size of his estate, nor will he attempt to stretch his borders outwards or straighten them by going after his neighbor's "sweet little field" (the diminutive again expresses a mindset full of desire) that juts into his own. To extend or diminish one's boundaries in this way would be to transgress limits overseen by Hermes as the god who sets and secures the boundary markers of the farm. And yet the prayer's expressed worry has to do with not just setting limits, but with making the place "his own'. Taking this as a worry that concerns not only a keeper of boundaries but the god of the lyre, the prayer touches on an issue that is both very real and current for Horace as he sets out to write his Odes, an issue famously agonized over in Odes 1.1. There the poet worries how he is to claim a place for himself in a generic space that is by now well worked and canonically set. Here the generic worry is figured in agricultural terms: will he perhaps strike it rich the easy way, by digging up some former owner's pot of gold? If not, what new variety of song can he expect to grow in such an oddly shaped and unusual (denormat agellum) little field? What will be the special produce of his garden, and the quality of his sheep? These are the bigger questions that figure into the poet's opening prayer to Hermes in Sermones 2.6.

So far the protasis, with its strong suggestions of Horace's having new bounds to keep to, as set for him and overseen by Mercury/Maecenas. The apodosis of the prayer leaves little doubt that for Horace Mercury is not a god of financial success in the usual terms. In it we catch sight of the poet in possession of another man's sheep. He prays to Mercury (lines 14-15): "Make the sheep fat for the (villa's) owner, and everything else, except his talent." As if to suggest that Callimachus was this field's previous owner, or perhaps to provide ironic proof that he has been stepping across his own boundaries to steal from another man's (generic) field, Horace models his prayer after famous 
programmatic passages in Virgil and Callimachus, so there is no escaping the idea that the speaker's farm and his poetry are somehow conceptually fused. ${ }^{30} \mathrm{~A}$ pleasing sacrifice requires a juicy victim, the fatter the better. Horace wants to grow a sheep nice and fat for his patron/god, but he worries that the sheep's being well fed will have a deleterious, "fattening" effect upon his own talent ('fat" the vice of the grand style). The poet has a rich and tempting larder to draw from on his farm, but he is determined to keep himself lean. A strange idea, and quite funny (Horace was apparently built like a fireplug), but the idea of growing too fat in his talent represents a very real threat to the poet, now that he can be counted as the villa's "owner" (dominus). With that title have come expectations of a "fat" payback, as the poet is now expected to respond in kind, with a voice suitably full and "rich" with praise. ${ }^{31}$ This is especially true after Actium, a time-marking event (see below) that broods over the entire book, just as it broods over the Epodes and Georgics books 3-4, informing Maecenas" urgency in all of these works to have his poets finish with what they were doing and get on to writing projects much more inspired and monumental..$^{32}$ Seen this way, the poet's "keep my talent lean" prayer applies at least as much to Maecenas as it does to Maia nate. Ultimately he, Maecenas, will set and oversee the boundaries of the poet's new field, both as a measure of land, and as a poetic project. It is he who will determine just how "fat" this poet's talent, and the yields of his new field, will have to be. Horace worries. He has already indicated that the place Maecenas gave him is somewhat bigger than what he had in mind.

We have seen that, in the country, the poet imagines himself in a time zone without clocks, where sleeping late is de rigeur, and hours have no particular point or job to be done (inertibus horis, 61). ${ }^{33}$ In contrast, the routines of his city life are lean on sleep and bound to a strict, ordinal schedule of appointments and times. Everything in the city, he makes clear, is by the hour. Daybreak, hour number one, has Horace rushing off to Maecenas" house (ad Maecenatem, 31). Maecenas tells him to get downtown soon, "before two o'clock" (ante secundam) but to be back later for an important meeting with the scribes. He calls him by his nomen, Quintus, less to flatter him, I suspect,than to remind him "be back by five" (Quinte, reverti, 37). Five-O'clock Horace. ${ }^{34}$ That is who the poet is in this satire, and all he means to Maecenas. Five O'Clock, the Roman business-day's last frantic hour. ${ }^{35}$ Three lines later he reminds us that it has been "seven years going on eight" (septimus octavo) since he first got involved with Maecenas. So, with the painstakingly "ordinal" description of the poet's workaday life, there comes a clear sense of the clock's steady ticking. That, according to Kenneth Reckford, makes the question of line 44 hora quota est? "what hour is it?" all the more poignant: a way of punning on the poet's name to say "who are you,Horace?" For by his very name, Horatius is always doomed to be a man of the clock. To escape its chiming, so loud in this poem ('two...five...seven...eight'), he must find a way to escape himself, Quintus Horatius, "Mr. Five-O'Clock Hour," the highly regulated, steadily ticking self he knows from his scheduled existence in the city. But here again satire and city life are fused to a remarkably rigid schedule, for book 2 itself seems to have been structured as a kind of "day in the life" to put us in mind of the poet's urban routines. ${ }^{36}$

But something happens as we think back on the poet's time spent with Maecenas, now "seven years going on eight." Put that way, we think back to 37 B.C.E., the precise year when the friendship was struck, when Horace first travelled with Maecenas to Brindisi to settle that "big business" of his (magnis de rebus, S. 1.5.28 remembered in de re magna of 2.6.36), otherwise known as the Peace of Tarentum. ${ }^{37}$ Horace went along for the ride 
that time as comes "traveling companion," but he had no part in hammering out the treaty. So when he thinks back on that trip in $S .1 .5$, the poet gives the tag-along's view of its most important moments: he remembers the weather (bad), the food (burnt), the wagons and mules (bumpy), and he especially remembers a mock gladiatorial fight between two low characters in a Caudine tavern (brilliant fun). Anything but anything that matters. So different was life then, way back when the friendship was new.

Or was it? Clearly built into the description of the poet's life with Maecenas nearly eight years later (S. 2.6.42-58) is a sense of everything's having stayed just the same despite the relentless ticking of time (per totum hoc tempus...in diem et horam,47). The poet still takes wagon-rides with Maecenas (42-3), tagging along as his comes, and he is still stuck conversing with him, and necessarily "us" in our overhearing, about nothing that matters: the day's gladiatorial contest (44) and the weather (45). Conversations with Maecenas, he says, are hoc genus "of this type," a way of saying"of this genre. ${ }^{38}$ Such are his sermones "talks/conversations" with the great Maecenas, and such are his sermones with us. Nothing more than trifles, "things safely stored in a leaky ear" (46). In that aural reference we have yet another pun on the poet's cognomen, Flaccus. So now we have the full name, and with it, a full sense of the speaker's jaded self: Quintus (Quinte, 37) Horatius (hora quota est, 44) Flaccus (rimosa...aure, 46). And built into the name, at each of its three levels, is a clear sense of the poet's not yet being who he wants to be, and of the trifle-talking genre's no longer being enough. He does not want to be stuck to a schedule, satire's city schedule, that makes him Five O'Clock Quintus, dooming him to deal with aliena negotia "other people's business" and to obsess over their transient concerns and never to be his own man and have something to call "his own." And he wants to be more than Maecenas" handy hour-glass ("What hora is it, Horatius?') and a flaccid ear to "entrust with tidbits" (concredere nugas, 43). But that is where this genre, he now feels, and these "conversations," are stuck. They never rise to address anything that really matters.

But why? The poet in the story has a chance to address big political issues in the streetscene that follows the wagon ride, but again he fails to deliver. A stranger buttonholes him (S. 2.6.51-8):

Stranger: "O my good man, for it behooves you to know this, since you are in close contact with the gods, have you heard anything regarding the Dacians?" Hor. "Not a thing." Str: "Oh what a clever dodger you will always be!" Hor. "But let all the gods harry me if I know anything at all!" Str. "Then what about this? Will Caesar give the spoils he promised to his soldiers from Sicily or Italy?" He is amazed when I swear I know nothing, looking at me as some creature of exceptional and deep silence.'

In this passage we hear the loudest tick of the clock not only in the poem, but in the entire book. Dating the poems of Sermones book 2 is notoriously difficult because, although he lives his life in the city and comments on the life he lives there, Horace has precious little to say about the city's big events and it's current political discourse. This passage's reference to Octavian's post-Actian land settlement is a rare exception to that general rule. It stands out in an otherwise politically reticent book as its securest ante quem, and that puts final publication of the book some time in mid-to-late 30 B.C.E. Scholars are grateful to Horace for being uncharacteristically forthcoming here, glad to have the information that we desperately need to mark the time. But they have failed to note the clear irony of this poet's finally speaking up and giving us the kind of information we are so greedy to have in a passage that pegs him as a man of 
impenetrable silence, who is either unwilling or unable to say anything of real political significance. Standing in for us, his buttonholer makes clear that what is said of Horace in the passage can be said of the Sermones themselves. Both are politically taciturn to the point of their being teasingly, frustratingly inscrutable. Even the scholiasts seem aware of this. ${ }^{39}$ In wanting more, the stranger who stops the poet in the street speaks for the rules of the genre as he knows them from Lucilius. He expects more of these intimate "conversations" with Maecenas than Horace is willing to give. And so do we. "What is holding him back?" we ask. Lucilius would have said something. If he were alive he would express an opinion about Octavian's land-settlement after Actium. "Nothing from you, Horace? No opinion about land-confiscations generally? Strange that that topic should fail to concern you, of all people. Oh what a derisor you will always be!'

The interlocutor's last word, derisor, cuts deep. It applies most commonly to parasites, the bankrupt, starving shadows of the Roman elite who, in comedy, do anything at all, no matter how demeaning, to score a dinner with a well-off friend. ${ }^{40}$ Thus the stranger's remark, "what an artful dodger you will always be!" puts Horace lowest on the low couch. Maecenas" couch. His parasitic side-kick. Pay your dues in that role long enough and you will be handsomely paid. You may even get a plot of land, a "sweet little place" to call your own, like any good soldier upon retiring from Octavian's army. Such is the cost of success in Rome, and the way envious outsiders read. But the stranger's cutting remark also gets at the way Horace, as satire's derisor, speaks: dodgingly, never to the big issues, with abuse safely hidden beneath a web of encouragement. "Is this the way you will always speak?" the stranger asks. The poet's answer, "Let all the gods harry me if I know anything at all!" hides an ironic twist that is, itself, a sample of the parasite's double-edged derisio. Three lines before we were told that the stranger "consults" the poet (me consulit, 51) because he feels he is close to the gods (deos quoniam propius contigis) and therefore in-the-know about things of high political import. But Horace's gods are not gods at all. They are his friends in high places, the policy-gods, Octavian and Maecenas. ${ }^{41}$ Are they the ones who will "harry" him if he claims to know anything at all? Are they, and the pressures they bring to bear upon his voice, the reason that his "conversations" speak so ironically and amount to so little?

But there is another point to be made from this quasi-oracular "consultation." Here, for the first time in Horace's works, we have the poet figured as the "seer" or "priest" consulted on issues of grand, public import because he is in tune with the gods and can speak their will in times of crisis. He is laughably inept, which is to say properly satiric, in that role here, just as he was in the role of hymnist in the lines preceding. Thus again in this passage we find the poet playing at his genre's limits and showing us where his Sermo can and cannot go. Here it is described as so much urban chit-chat that keeps to meaningless matters in order to keep Maecenas on the poet's good side. Nowhere is the gap in status that separates Horace from Maecenas more gaping than it is here. There will be no twisted-napkin play between these two friends. That is clear. And the meals they share will not be of the boiled cabbage variety. They will be of the sophisticated business type, and Horace will have his role to play, and keep to, at these affairs. Still, he can dream. By teasingly sampling his ways of self-expression in another generic space, Horace floats before us, ever so briefly, the notion of his actually saying something that matters, by stepping into the role of vates, the poet-priest who 
interprets the will of the gods on matters of highest import in (often frustratingly cryptic) song.

Different generic spaces have their standard characters and themes. They have different settings, different moral systems and figurative habits, and different ways of seeing the world. By paying close attention to some of these differences, especially in habits of self-figuration, I have argued that a veiled topic of conversation in Sermones 2.6 is the poet's dream of finding contentment in another generic space. I suspect that the poem's famous concluding fable may touch on this theme as well by poking fun at Horace's longing not just for the countryside, but for the bigger generic world that the countryside is made to entail. Like Horace, the country mouse is a ridiculous dreamer. But both mice, not just the bumpkin, come off badly in the tale. Scholarly renderings of the fable routinely give the country-mouse the upper hand in having the poem's last say. But I see no clear winner here, and no easy moral about the superiority of country life over city life. Such indirection, I admit, seems strange coming from a poet so obsessed with the countryside early on in the poem. But we should remember that Horace puts a narrative fold between himself and us by relating the story as the "prattling" (garrit, 77) of a certain Cervius, one of his country neighbors, so we cannot automatically be sure how he, a starry-eyed dreamer, relates to it. We cannot even be sure that he, as a character in the poem, "gets" it. So perhaps this is not what it is usually taken to be, Horace's lesson to us on the theme of his dreamed-of rustic contentment, but Cervius" lesson to the dreamer within the poem, telling him to be wary of thinking that a new life awaits him, even his soul's transmigration, just by transferring his carcass to the countryside. Any good Epicurean of the time should know better, for when Lucretius tells his mouse-free version of the tale at DRN 3.1057-70, he argues that racing off to the country to find contentment is a sign of the racer's own internal confusion. The grass is not greener there, nor is the wine sweeter, because the main piece of luggage packed along is the fool's own, disoriented self. Since the trip brings no relief, the deluded fool heads straight back to the city. Thus, from city, to country, to city again, ad infinitum.

In Cervius" fable the poles of city and country are the same, but the point of origin is reversed: the place first escaped, then raced back to, is the country, not the city. And that makes the country-mouse stand in as the alter-ego of Lucretius" deluded fool. In the end, he is the one who gets big ideas and starts looking for a new life, not the citymouse. His urban cousin may be vain and pushy, but he harbours no delusions about finding contentment in the country. So it is not what we expect, not from a dreamer so clearly on the rustic rodent's side. But here again we must keep in mind that the story is put to the dreamer. Perhaps not what he exemplifies, admirably, in his longing for the country, but what he needs to hear about that longing. Yours is a pipe-dream, the prattled story says, because your old self dogs you wherever you go.

Many of the basic moral and literary oppositions built into the city/country dichotomy earlier in the poem break down in the fable..$^{42}$ Their breaking down, I think, is the point, and a way of exposing the cracks in an all too perfect dream. For example, it is often noted that the city-mouse lives a parasitical existence in feasting on a rich man's leftovers. He pretends to "host" a meal for his visiting friend, but he succeeds only in exposing his servility (clearest in lines 107-9). This contrasts with the remarkable independence of the country-mouse who, although he serves paltry fare, reclines with 
his guest (signalling free status) as pater domus "father of the house." He is an owner, not a pretender, and that is just the way Horace dreamed it would be in the country.

But there is something odd about the way the country-mouse "loosens his tight disposition" for his visiting friend that makes me think that his independence is also a ruse, and that his escape from a mouse's quintessential parasitism is far from complete. ${ }^{43} \mathrm{He}$ serves his visitor a chickpea "set aside" (sepositi) for the occasion, an oat-stalk, a raisin, and a bit of half-eaten bacon. These, to an item, are the domesticated foodstuffs of a Roman villa. They do not suggest foraging in the wild, but stealing from the farmer's larder or barn. The telltale image is that half-eaten bacon. That had to fall from the farmer's table, or have been stolen from his shelf. It is half-eaten because the farmer ate the better half of it. And what of the saved up chickpea? Who was saving it, the mouse or the farmer? Just how independent is this little mouse? That "hole" (cavo) of his that he calls "home" (domus) is no underground burrow or tree hollow, it is a hole in the farmer's wall. Even the palea "chaff" on which he reclines as exalted pater ipse domus suggests that he has been stealing from the threshing floor, an interloper in the house he calls "his own." Look out for the farmer's cat, little mouse! Plenty of those in fables too.

No matter where these mice find themselves, they still find themselves, just as Lucretius said they would. And that is the real problem. For despite whatever airs of independence and/or sophistication they may put on to impress one another, they are still only, and ever will be, mice, notoriously (and for Romans, by nature) parasitic, and all the more ridiculous for having tried to be something more. So who really is the fool in this story? More to the point, who isn't a fool? The desire to escape to some better place is a mirage either way: the country entails the city, and the city the country. And that is the particular way this story scolds Horace for wanting to run away to a rustic Neverland, and us for believing that he could. It does not allow the poet, or us, to situate our problems "out there" in the world, as simple matters of geography and of daily routines. It makes us look inside, to the problem of our own desiring, and of our never being able to live with, and within, ourselves.

Carpe viam "sieze the way" the city mouse says to his country cousin. He reminds him that "earthly creatures" (terrestria, 93) are allotted mortal souls, and that death awaits both great and small (magno aut parvo, 95). Live it up, he says, because life is short. He should know. He is a mouse. And life doesn't get much shorter, or creatures lower to the ground (terra), than that. Here, again, we have another lyric first done up in satiric guise. The carpe diem refrain of Horatian lyric is done up in loving detail, complete with Epicurean melancholy and warnings of death's relentless approach. But the poles of city and country are reversed: in the Odes, the invitation to grab life while you can is normally issued from the country poet to someone not yet there. It calls the harried aristocrat, or an unwilling lover, to the countryside, inviting them to set aside their workaday concerns and come take some wine streamside, under a particularly shady tree. So shouldn't the country mouse be the one issuing such an invitation, reminding his city cousin that life is short, and that he should slow down and really live it up before he dies? If we thought that Horace was the country mouse in the story, we are stunned by the peculiar packaging of the invitation. That is his lyric voice, and his signature subumbral motif. So where do we place him in the story? Country mouse? City mouse? 

some work they can be extracted from it, but they are not instantaneously offered up by it. The curious blending of the city with the country, and vice versa, is one of the more problematic features of the fable. It suggests that neither locale is half as carefree or grand as the big-talkers on both sides say they are. The point may rather be about their talking big, not about one's having a more reasonable set of values than the other. Go to the city, the tale says, and you will find yourself beset by some of the same problems that you thought you were leaving behind, chased down by Molossian hounds, the legendary best friends of the shepherd, the hunter, and the farmer. ${ }^{44}$ In the country such fine animals are indispensable. But in the city those dogs live a pampered life growing fat on yesterday's feast. They are the biggest, and the most bullying of the house's panoply of parasites. On the rare occasions when duty calls on them to protect the master's fine silver they overplay their part magnificently, putting on a good show for the master by howling "to the heights of the house" (domus alta...personuit) as if back in the mountains, chasing along a high echoing ridge, hot on the trail of a wolf or a boar. Their mouse-hunt is reminiscent of the poet's alpine chase in Epode 6.5-10:

nam qualis aut Molossus aut fulvus Lacon, amica vis pastoribus,

agam per altas aure sublata nivis quaecumque praecedet fera;

tu, cum timenda voce complesti nemus, proiectum odoraris cibum.

Like a Molossian or a tawny Laconian hound, the shepherds" fierce friend, with ears lifted high I will chase whatever beast runs ahead of me through the deep snow. However, once you have filled the grove with a frightful howl you start sniffing, hot on the scent of scraps tossed your way.

the end of Sermones 2.6 the bounding and the noise are all for show, since a mere creak of the hinges is enough to send the mice scurrying. But like the worthless but well-fed dog of Epode 6, these dogs know that the master loves it when they bark like the old days. "To battle, lads, and to certain death! The leftovers must be protected at all costs!" Overplay that part well enough, and those leftovers will be tossed your way.

Shepherding dogs. The country mouse is used to having them about, but he didn't expect to have to deal with them in the city. His luck isn't just bad, it's ironic. But go to the country, this tale says, and you will find mice behaving badly and putting on airs to impress their citified friends with city-inspired displays (varia...cena) parading as rustic simplicity. Yes, the food is simple and nourishing there, the mousey equivalent of what Horace dreams of eating earlier in the poem. And it is the same salt-of-the earth stuff that the poet has dished up for our consumption since the beginning of book one (iam satis est) and that he apparently no longer regards as "enough" (auctius atque di melius fecere). But simple foods do not spontaneously drop from the trees in the country any more than they do in the city. For there, too, the mouse only plays at being his own mouse, the exalted pater ipse domus, since the very chaff he reclines on belongs to someone else. Nonetheless he puts on an impressive show of independence for his citified friend. But the city mouse knows his old chum a bit too well to be taken in by it. For one thing he knows that his old friend is a sucker for savory fare, so he invites him to tag along on a quick trip to the city as his "travel companion" (carpe viam.... comes), the very role that Horace played for Maecenas earlier in the poem, and that he has been playing for seven years going on eight. The rustic mouse is either easily duped, or he has been pretending all along, as he literally "jumps" at the chance to leave his old life 
behind (domo levis exsilit), off like a flash, no questions asked. So much for his being deeply committed to the simple life. And it should be noted that his serving such a rock-hard feast to his old friend turns out, in the end, not to have been such a bad idea. An envious outsider might even suggest that it was all too perfect, and that it had to be planned to turn out this way. After all, were we not explicitly told that these mice are the oldest of old friends and long-time veterans of one another (veteremvetus hospes amicum, 81)? How can it be that the country mouse does not realize - surely he does that his urban friend does not like eating sticks and stones for dinner, and that he won't put up with eating this way for long. "Surely you knew, little mouse, that your friend would eventually say "to hell with this" and drag you off to the city to dine on lobster cakes and foie gras. And, naturally, once there you will overplay the role of a bedazzled hick, since your friend just loves it when you pretend to be impressed with him, amazed at how ample and big (multa...magna, 104) and expensive (locuples, 102) and shiny (canderet...eburnos) everything is. Oh, what a derisor you will always be!'

In his dealings with the city mouse, the country mouse has a good deal of Horace about him, a well-kept Molossian pup eager to play the happy dinner-guest (laetum convivam, 111) for Maecenas. Or is the point rather that the city mouse has a good deal of Maecenas about him in knowing how to play his old friend, Horace, like a finely tuned lyre? A mouse of refined tastes, he knows how to put pressure on an old friend and get him to do what he wants. He knows that, for all of his rustic posturing, his friend can easily be taken in by the enticements of a big feast (ma-gna superessent fercula cen-a). The story, I suggest, cuts both ways, putting emphasis not on how one mouse uses the other, but on how each uses the other while pretending that he does not. The point is thus about the tacit agreement that they share between themselves that allows them to pretend that their friendship is a healthful and improving one, and always based on the best of intentions (ad amicitias ustsrectum...trahat nos, 75).

Like either mouse in the story, Cervius seems to know his old friend, Horace, too well to be taken in by his big talk of contentedness and plain living, the very stuff he has been trying to sell us from the start of the poem by playing at being the independent, happy bean-eater every other weekend on his farm. The charge that Davus levels against him in the next poem seems tailor-made to put us in mind of Cervius" fable (right down to the city-country chiasm of the first line), and to let us know just how quickly Horace is prone to tossing aside his diet of wholesome philosophical sermo and vetch for something racy and high in fat (7.28-35):

Romae rus optas; absentem rusticus urbem

tollis ad astra levis. si nusquam es forte vocatus

ad cenam, laudas securum holus ac, velut usquam

vinctus eas, ita te felicem dicis amasque,

quod nusquam tibi sit potandum. iusserit ad se

Maecenas serum sub lumina prima venire

convivam: "nemon oleum fert ocius? Ecquis

audit?" cum magno blateras clamore fugisque.

At Rome you long for the country. In the country you praise the city to the skies. Fickle man. If it happens that no one has invited you to dinner you praise a carefree diet of vegetables, and you say that you're delighted with this, and you congratulate yourself for not having to go off somewhere and get drunk, as if they'd have to drag you away in chains. But if Maecenas tells you to come to dinner right as it's getting dark, a last minute guest, you burst out shouting "Doesn't anyone listen around here? Quick, where's my oil?!” and you make your escape. 

for Horace. To believe that is not to know Horace at all. For no matter how simple and attentive to clean moral living his Sermones play at being, his old friends know that for him getting the farm is not about iam satis est, it is about finally bringing together all the basic trappings of an elite Roman male into a nice tidy pile. The rules say that to count as the real thing, to be somebody in the city, you have to own a country place outside of it (but not too far off) where you can play at being Cincinnatus, by wearing overalls and sweating and stinking of shit and swearing that that kind of life suits you best, and that it is the best and surest indicator of who you really are. "O.k., Mr. Dreamer," Cervius seems to say with his fable, "let's see you steer that plow straight. Do you even know which end of the horse to hook it to?'

The last line of the fable, though it states no explicit moral, balances advantages against disadvantages in its first and last words: tutus ab insidiis tenui solabitur ervo. As if to say: "Vetch. That's what I'll be eating. Nasty stuff. Keeps me thin. But at least I'll be safe." By design, the poem's last word leaves a bitter taste in our mouths, and thereby it leaves us to wonder just how long this mouse will retain his composure before spitting the stuff out and going off on his next binge, when his next serious craving kicks in, for shellfish, and pastries and "to hell with those Molossian dogs, I want some toasted thrushes tongues!" That is also the Horace that Cervius seems to know in telling the story the way he tells it. In the alluring promises of the city mouse, Cervius makes Horace deal with his ever-discontented self, and all the dreams that go with working his rich new fields (of song). In accepting Maecenas" invitation he will end up right back where he started, facing the same old problems that he seemed so anxious to escape. But can he really ever escape the pandering rat-race of the city when he is so clearly enamoured of the city's parties, its pleasures and prestige? Wherever he goes, and in whatever genre he chooses to express himself, what chance does he have of escaping himself? Horace, the dreamer of this poem, hears the story and seems irritated by the truth of his neighbor's "prattling." Does he really think that Maecenas will leave him with nothing to do out there in the country? Does he really think that envy will bite him less, and that Romans will take to regarding him, finally, as selfmade, and master of his own house, rather than as a lucky "son of fortune" (fortunae filius, 49), a tag-along and a his master's well-fed pet? Dream all you want, the story says. This is Rome. And its drudgeries, schedules, and sneers are not easily left behind as long as you are, well, you! That villa of yours, and the song-work it entails, may enmire you in city life, its traditions, tales, and politics, in ways beyond your imagining. And that is exactly what it does. In song.

But this story is not just about the poet's "dreaming forward" towards a too-perfect generic space where he fails to see the dogs lurking in the shadows. It is about all the expectations that we heap on these poems to keep the poet constrained, right where we need him to be, and somehow not at home in the place he's stuck. If this poet is prone to pipe-dream and run from one place to the next it is because we expect him to sermonize or sing an old favorite song for us in ways that suit our notions of what counts for Sermo and song. That is the theme that opens book 2 of the Sermones, with the poet constrained by extreme and uncompromising expectations (nimis acer...sine neruis), and Trebatius there to serve up a handy set of options for whatever it is you want from this poet, both in this work and the next: anything from utter silence and just barely managing to stay alive, to making a killing with loud-clanging songs of 
martial conflict and praise of Octavian's glorious victory at Actium. It is a problem easily solved, Trebatius says, like choosing wallpaper: just choose a mode. But make sure that it is a pre-existing mode, well marked off and ready to go, like the ones we already know and love. The one possibility that Trebatius, a man of the book, does not seem ready for is the idea that Horace might try something that is not already neatly indexed in his book, something mode-straddling and new, or a strange mix of every possibility he has just mentioned. And that seems to be a consistent non-expectation of all the various inset readers and helpful advisers who berate and prod Horace in the course of Sermones book 2. They all want something monological and monolithic from him, not something that they don't already know, and certainly not something that keeps them guessing.

But that is what Horace serves up in the second book of his Sermones, the camouflage and smoke of Plato and Menander, Lucilius and Varro, and so on. And this is largely how he operates in books 1-3 of the Odes as well.Damasippus can't stand it. He wants a strong and urgent moral voice, doggedly committed and tragically overdone in the tones of his beloved Stoic diatribe. The buttonholer in poem 6 wants something politically telling, the tattler's inside scoop. Trebatius, Teiresias and Davus, too, they all know what ails this poet. Each wants only the satirist that he went looking for, the one that, he is sure, Horace could be if he would only shape up and give it a try. Horace lets us sense their disappointments, all the while making clear that they are standing in for us, and all that we expect of him. And in that gesture he lets each reader curiously regard his own need to have the Horace they went looking for, and to put these poems securely in their (pre-existing) place. By mixing things up these poems keep us guessing and feeling unsettled and got at. What we make of this, and the way we make sense of the book to produce a satirist with a point, tells us who we are: a Damasippus, a pushy City Mouse, or some manner of rodent in between. What we end up with is the book of poems, and the moral to the tale, that we deserve. And that may be the most damaging insult that these poems can toss our way.

\section{BIBLIOGRAPHY}

Barchiesi, A. (2001) "Horace and Iambos: The Poet as Literary Historian," in A. Cavarzere, A. Aloni, and A. Barchiesi, eds. Iambic Ideas: Essays on a Poetic Tradition from Archaic Greece to the Late Roman Empire, 141-164. Lanham MD.

Citroni, M. (2000) "The Memory of Philippi in Horace and the Interpretation of Epistle 1.20.23," Classical Journal 96: 27-56.

Cody, J. (1976) Horace and Callimachean Aesthetics. Brussels.

Cucchiarelli, A. (2001) La Satira e il poeta: Orazio tra Epodi e Sermones, Biblioteca di Materiali e

discussioni per l'analisi dei testi classici 17. Pisa.

Fedeli, P. (1994) Q. Orazio Flacco: Le Opere II, Le Satire. Rome.

Fraenkel, E. (1957) Horace. Oxford. 
Freudenburg, K (2001) Satires of Rome: Threatening Poses from Lucilius to Juvenal. Cambridge.

Gowers, E (1993) The Loaded Table: Representations of Food in Latin Literature. Oxford.

Harrison, S. (2001) "Some Generic Problems in Horace's Epodes: Or, On (Not) Being Archilochus," in A. Cavarzere, A. Aloni, and A. Barchiesi, eds. Iambic Ideas: Essays on a Poetic Tradition from Archaic Greece to the Late Roman Empire, 165-186. Lanham MD.

Labate, M. (1981) “La satira di Orazio: morfologia di un genere irrequieto', in Orazio, Satire, 5-45. Milano.

(1996) "Il sermo oraziano e i generi letterari," in Zeitgenosse Horaz: der Dichter und seine Leser seit zwei Jahrtausenden, 424-441. Tübingen.

Muecke, F. (1993) ed. Horace Satires II. Warminster.

Neumeister, C. (1976) “Horaz und Merkur," Antike und Abendland 22: 185-194.

Oliensis, E. (1998) Horace and the Rhetoric of Authority. Cambridge.

Reckford, K. (1997) “Horatius: the Man and the Hour," American Journal of Philology 118: 583-612.

Watson, L. (2003) A Commentary on Horace's Epodes. Oxford.

\section{NOTES}

1. Fraenkel (1957) 138 n.1 thought that hoc erat in votis was perhaps "an echo of a set phrase which was used when someone, in thanking a deity, said that the wishes which he had uttered when making his vow were now fulfilled." The idea is seconded, without elaboration, by Fedeli (1994) 699.

2. Fr. 42 Dg. $(=32 \mathrm{~W})$

a) Hermes, dear Hermes, Maia's son, Cyllenian, hear thou my prayer, for I am bloody frozen, my teeth are chattering...

b) Grant Hipponax a cloak and a nice tunic and some nice sandals and nice fur boots,and sixty gold sovereigns to balance me up... [tr. West]

Fr. 43 Dg. (= $34 \mathrm{~W})$

For thou has never granted me a cloak thick in the winter to cure me of the shivers, nor hast thou wrapped my feet in thick fur boots to stop my chillblains bursting. [tr. West]

3. See PseudoAcron at Sermones 2.1.72.

4. For a thorough study of Horace's programmatic division of Lucilius into two "poles" of satiric purpose and expression, mordacità critica and poesia personale-autobiografica, see Labate (1996). For an earlier and fuller effort along these same lines, see Labate (1981).

5. On the ironic tension produced by the placement of Sermones 2.6 (home found) directly on the heels of 2.5 (looking for home), see Freudenburg (2001) 99.

6. The satirist's retreat to his villa to escape the bustle of the city may have a precedent at Lucil. fr. 636-7W. The opening of Cicero's ad Att. 2.1 seems to recall the Lucilian escape: Kal. Iuniis eunti mihi Antium et gladiatores M. Metelli cupide relinquenti venit obviam tuus puer.

7. Or perhaps he has read epod. 11.3-4 amore, qui me praeter omnis expetit / mollibus in pueris aut in puellis urere.

8. Athen. 10.429b: "Anacreon, who made all his poetry depend on the subject of intoxication, is unusual. For he is attacked as having given himself over in his poetry to laxity and luxury, since most people are unaware that he was sober while he composed and that he was an upright man,

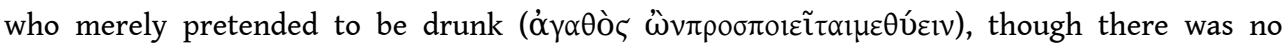
necessity for his doing so." (trans. D.A. Campbell, Loeb Classical Library) 
9. He does use carmina twice in Sermones 2. But as Cucchiarelli (2001) 150-152 points out, these references may well refer us outwards, to the Epodes. Throughout Sermones 2.1 there is a split perspective on the poetry of Lucilius. The claim of lines 62-3 est Lucilius ausus / primus in hunc operis componere carmina morem refers us back to the description of lines 40-56, where Lucilius" poetry is characterized by the specific figurative terminology of iambic poetry: sharp weapons, rust, poison, wolves, biting, bull's horns, magic and incantation. None of this applies well, if at all, to what follows in Sermones book 2; see Watson (2003) 254: “In its exploration of the iambist's persona, Epode 6 is akin to Sermones 1.4 and 2.1, both of which dilate upon the function of the satirist. In particular it exhibits a conspicuous resemblance to lines 39-46 of the latter, which outline for the practitioner of the genre an essentially retaliatory role." For the mismatch of the violent programmatic claims of Sermones 2.1 to what is delivered in the rest of the book, see Rudd (1966) 124-31. The specific terminology of Sermones 2.1.40-56 reminds us that Lucilius did, in fact, write iambs in his earliest books, and that some of his hexameter poems are fully "iambic" in tone, holding to the so-called "iambic idea" without being metrically/technically iambic. But both earlier and later in the same program poem, we have seen, Horace characterizes Lucilius" poetry as occasionally "off stage" and relaxed, personal, and confessional. And this fits the type of poetry that we find in Sermones book 2 quite well. Thus (and here I owe a debt of gratitude to Cucchiarelli for introducing me to the idea) it seems that Sermones 2.1 finds Horace splitting what was in book one a single Lucilian enterprise into two separate generic camps. The attacker (of a certain low-key Horatian sort) he will shuttle aside to the Epodes, while the confiding friend he will leave in place to conduct the conversations that follow in Sermones book 2.

10. Frances Muecke has recently argued that the phrase refers to the "exceptional nature" of Horace's conversation pieces, that is, as something that hovers between common talk and song See F. Muecke, Horace Satires II (Warminster, 1993) ad 2.6.17. This is a superb suggestion, but I do not want to rule out the possiblity that the "singing" referred to here might also touch on quite another issue, that of the poet's current and/or projected forays into lyric.

11. Besides having a name with a famous background, Phryne's designation as libertina marks her as a prostitute. See Watson (2003) 194.

12. Watson (2003) 190.

13. Most recently Watson (2003) 440: "When Horace states that amor prevents him from writing iambi, or alludes in 9-12 to the precedent of the lyric poet Anacreon, he may be saying obliquely that he no longer finds artistic satisfaction in iambic poetry, that his thoughts are turning to amatory Odes." For bibliographical support, see n.14 (same page). For the tradition that regards Anacreon's style as neat and unaffected, see Hermog. Id. 2.3 (p.322 Rabe), and Watson (2003) 451.

14. See Nisbet-Hubbard vol. 1 (1970) 215 and 224.

15. Legend held that Anacreon and Polycrates of Samos were rivals for the attentions of Bathyllus. According to Tacitus Ann. 1.54.2 Maecenas was in love with a pantomime actor of the same name, so Horace may be alluding to a contemporary Bathyllus as well; see Watson (2003) 449.

16. For relevant bibliography, see Watson (2003) 198 n.51.

17. By far the best study of Damasippus" book-bag is Cucchiarelli (2001) 168-179. I follow Cucchiarelli in seeing a natural fault line running through the contents of the bag: "è facile, a questo punto, riconoscere in questa distinzione tra autori di "prosa" e autori di "poesia" la distinzione stessa tra I Sermones e gli Epodi" (p.170). I would simply add that the Plato/Menander half of the equation seems carefully crafted to refer to the peculiar contents of book 2, the current project, rather than to the Sermones taken as a whole. See Freudenburg (2001) 116-117. For Archilochus as a dynamic model (i.e. beyond a mere pre-existing point of reference) in Horace's Epodes, see Barchiesi (2001) and Harrison (2001). And, naturally, Horace himself, Epistles 1.19.22-5: Parios ego primus iambos / ostendi Latio, numeros animosque secutus / Archilochi.

18. His tirade hides a serious theoretical issue of polyeideia. 
19. The longing for sleep and forgetfulness is a first clear hint of the poet's delusion (see below). He stands in as the fool of Lucretius 3.1057-70 who, upon arriving at his country estate: aut abit in somnum gravis atque oblivia quaerit / aut etiam properans urbem petit atque revisit (1066-7).

20. His followers abstained from beans, believing that they housed the souls of the dead.

21. See Freudenburg (2001) 21-51.

22. For example Sermones 1.6.115-18.

23. This passage is Pindaric. Olympian 2 begins: "what god, what hero, what man shall I celebrate

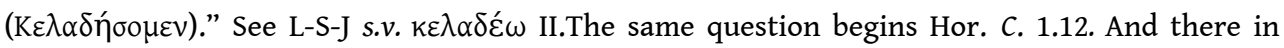
stanzas 2-3 the location is clearly high in the (inspired) Mountains. For pedester meaning "without

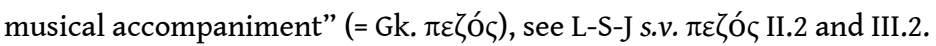

24. This is just the second (and it is the last) time Horace will use satura in its technical, literary sense in his extant works. In its only other use at S. 2.1.1 he uses the term precisely because of its strong associations with Lucilian invective. See Muecke (1993) ad 2.1.1.

25. The term is given specifically Augustan ('monumental" brick-to-marble) associations by Livy in his preface: Hoc illud est praecipue in cognitione rerum salubre ac frugiferum, omnis te exempli documenta in inlustri posita monumento intueri.

26. E.g. C.1.12.1-13: Quem virum....quem deum...quid prius dicam?

27. For Maia nate hinting at Maecenas, see K. Reckford, "Horatius: The Man and the Hour," American Journal of Philology 118 (1997) 595, and E. Oliensis, Horace and the Rhetoric of Authority (Cambridge, 1998) 48.

28. For the poet's special affinity to Mercury, see Citroni (2000), esp. p.41 n.28, and Neumeister (1976).

29. See Citroni (2000) 41, n. 28.

30. Bluntest of all in connecting elevated song to a fat paycheck, perhaps even earning the poet a place of one's own in the mountains, is Calpurnius Siculus, especially in his fourth eclogue; e.g. Calp. Ecl. 4.152-155: O mihi quam tenero decurrunt carmina uersu! / Tunc, Meliboee, sonent, si quando in montibus istis / dicar habere Larem, si quando nostra uidere / pascua contingat! For slender holdings as an aesthetic symbol in S. 2.6, see esp. J.V. Cody, Horace and Callimachean Aesthetics (Brussels, 1976) 104-8. I have a habit of reading the poets" sheep/goat feeding and ownership this way. See Freudenburg (2001) 41-44.

31. As Ep. 2.1.267 ne rubeam pingui donatus munere, where the "gift" in question is an overdone poem of praise offered in exchange for the poet's financial enrichment.

32. For the race against the clock signaled by Sermones 2.1 and Georgics 3 (proem), see Freudenburg (2001) 77-82. What scholars fail to tell us in noting that Georgics 3, Sermones 2.1 (and I would add 2.3), and Epode 14 all feature inset characters who push the poet to get done with his current project (tua, Maecenas, haud mollia iussa, G. 3.41) so that he can move on to something else, is that: 1) all three of the projects just mentioned were being written at the same time; 2) all three of them begin on a deliberately Actian note; and 3) the theme of being pushed to move on to the next project does not appear in any of the poets" pre-Actian projects. Clearly, if these works are racing against the clock, the starting gun of the race is the Battle of Actium.

33. On the theme of poetic inertia, see Watson (2003) 438-41.

34. Reckford (1997) 586 brilliantly connects the praenomen to the poem's ordinal ticking: "The praenomen, as used here, may indicate a false familiarity... More significantly, I think, it represents Quintus (Horatius) as a "fifth-hour" man." My arguments here for the poem's temporal obsessions and naming puns draw heavily on Reckford's remarkable work.

35. Reckford (1997) 587: 'Business quiets down at the sixth hora, ends reliably by the seventh.'

36. Poem 1 describes an event that was known to take place at the crack of dawn, and poem 2 is set before the lunch hour (impransi mecum disquirite, 7). The third poem catches the poet sleeping in after a hard night of writer's block - in his imitation of this poem Persius will put the time of the slaggard's berating at the fifth hour, high noon, the end of the typical Roman work day (P.3.4 
quinta... umbra). Poem four is on the same schedule as Plato's Phaedrus (set in the heat of the afternoon), after the morning lesson but with thoughts turning towards dinner. Poems 5-7 don't seem bound to any particular hour of the day. But the last poem, number 8 , recounts a feast that goes late into the night and (like Trimalchio's feast) just won't end. Thus we go roughly from sunrise to the dead of night, a day in the life.

37. On the difficulties of extracting an exact historical point of reference for the events described in Sermones 1.5, see Gowers (1993).

38. For the connections of genus (genre) to social rank, see Freudenburg (2001) 48-49.

39. At line 58 Pseudo-Acro refers us to 1.4.17-18, where raro et perpauca loquentis is, given its context, as much a matter of poetic production and aesthetic values as it is a description of the poet's personality (the scholiasts would have regarded these as naturally synonymous, but for Horace their synonymity is an idea he works at and has fun with to achieve various perspectives and effects).

40. Cf. Ep. 1.18.10-11 imi / derisor lecti sic nutum divitis horret.

41. Pseudo-Acro annotates deos in line 52 with: idest Augustum et Maecenatem, ut "namque erit ille mihi semper deus", referring to Virg. Ecl. 1.7.

42. Oliensis (1998) 50: "The multiple oppositions that frame and structure the tale of the two mice - between wealth and poverty, vice and virtue, danger and safety, servile dependence and manly (mousely) independence, city and country - line up with a certain conventional neatness in parallel columns. But in Horace's case, the columns are not parallel but intertwined, and the accounting cannot be so simple." I question whether the parallels really are so neatly opposed even for the mice.

43. Ergasilus defines his parasitic ways as mouse-like at Plautus Capt. 77: quasi mures semper edimus alienum cibum. Cf. the story of Diogenes" murin at Diog. Laert. 6.40.

44. The molossus isn't just a dog, it's a metrical foot. Horace's use of it after the third- strong caesura in lines 106-111 (five times in six lines) is unprecedented. Thus the house is resounding with Molossians in that sense as well. On this particular feature of the hexameter line as a neoteric tic, see Freudenburg (2001) 98, with fn. 129.

\section{ABSTRACTS}

In this paper I look at the ways in which certain poems of Sermones Book Two and the Epodes routinely look past their own generic horizons to spy on an alternate, and highly idealized, poetic landscape that lies just ahead in the poet's career. Like rich fields waiting to be developed and tended, the Odes occupy the poet's time and thoughts in the late 30's B.C.E. These 'singing' poems, like a newly purchased farm, await his full-time attention, even while he is still deeply enmeshed in the life of the city and the generic enterprises that need to be finished there. The Odes, poems given special urgency by Octavian's victory at Actium, are thus constructed as a dreamscape that the poet wants to enter but, as yet, cannot. To make my case, I focus especially on Sermones 2.6, treating that poem's many extra-generic glosses not only as a means of locating the host-genre's center, but as a way of chafing at its too narrow limits, and perhaps also as a way of signaling how the poet intends to break new ground in the Odes, as a poet deeply committed to mode-mixing, variation, and ironic play. The pressures and restrictions that come with being a satirist in 31-30 B.C.E. are played out in this poem. And Horace's own extra-generic pipedreaming, I suggest, is at the heart of its concluding fable. 
INDEX

Mots-clés: Horace, Hipponax, Epodes, Sermones, satire, Lucilius, fable, Anacreon, lyric poetry, Carmina, Maecenas, Pindar, epinician poetry, cena, polyeideia 